\title{
Edward Ozorowski, Słownik podstawowych pojęć teologicznych Wydawnictwo UKSW, Warszawa 2007, ss. 376
}

„Każda dobra encyklopedia ma charakter informacyjny i stara się unikać oceniania i wartościowania osób, wydarzeń i zjawisk, które wyszczególnia i zwięźle opisuje. Zawiera zbiór wiadomości ze wszystkich dziedzin, bądź z jednej rozległej

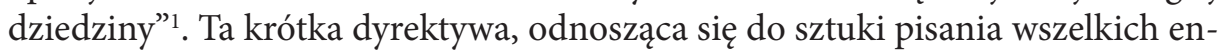
cyklopedii, słowników, wyznacza sposób realizacji tego przedsięwzięcia. Każdy słownik, niezależnie od dyscypliny naukowej, której dotyczy, powinien bowiem spełniać następujące kryteria : charakter informacyjny, obiektywność, zwięzłość wypowiedzi.

Również teologia, jako dziedzina nauki, posiada zasób pojęć, domagających się wyjaśniania. Wśród licznych słowników, przybliżających zagadnienia teologiczne - m.in. Słownik teologiczny pod red. A. Zuberbiera z 1985 roku czy też Encyklopedia biblijna pod red. J. Achtemeiera z 1999 roku - prawdziwą perełką jawi się Słownik podstawowych pojęć teologicznych autorstwa abp. prof. dr. hab. Edwarda Ozorowskiego, wydany w Warszawie w 2007 roku, nakładem Wydawnictwa Uniwersytetu Kardynała Stefana Wyszyńskiego.

W dorobku naukowym ks. Arcybiskupa można odnaleźć blisko dwa tysiące prac z zakresu historii teologii, teologii dogmatycznej, eklezjologii, antropologii chrześcijańskiej, mariologii, teologii małżeństwa i rodziny. Wszystkie wypowiedzi, wychodzące spod pióra tegoż Autora, cechują się kunsztownym, wspaniałym stylem, osiągniętym poprzez prostotę wypowiedzi przy jednoczesnym wnikliwym, rzetelnym, specjalistycznym i wieloaspektowym wykładzie trudnych zagadnień teologicznych. Owa erudycja ks. Arcybiskupa uwidacznia się również w Słowniku podstawowych pojęć teologicznych, który powinien znaleźć poczesne miejsce w księgozbiorze nie tylko wykładowcy akademickiego czy studenta teologii, lecz każdego człowieka, pragnącego zrozumieć swoją wiarę.

$\mathrm{Na}$ czym zatem polega wyjątkowość tegoż dzieła? Czym różni się od innych książek tego typu? W czym przewyższa panteon słowników, licznie ukazujących się na rynku wydawniczym? Odpowiedzi na powyższe pytania znajdziemy, rozważając , na jakiej zasadzie w prezentowanym dziele funkcjonują kryteria słownikotwórcze, wyszczególnione przez ks. W. Chrostowskiego: charakter informacyjny, obiektywność, zwięzłość wypowiedzi.

W. Chrostowski, Słowo wstępne, [w:] F. L. Cross (red.), Encyklopedia Kościoła, t. 1, Warszawa 2003, VIII. 


\section{Charakter informacyjny}

W Słowniku odnajdujemy kluczowe pojęcia teologiczne. Wspaniały kunszt Autora pozwala każdemu czytelnikowi zrozumieć nawet najbardziej zawiłe zagadnienia. Na czym polega wyjątkowość omówienia haseł w tym dziele? Tajemnica kryje się we wspaniałym stylu pisarskim ks. Arcybiskupa, dyskretnej dynamice wypowiedzi, w której wiele treści jest podanych w zwięzłej, przejrzystej formie. Pojęcia są wyjaśnione wyczerpująco, ale nie zamęczają czytelnika nagromadzeniem słów, zawiłych ozdobników myślowych - wręcz przeciwnie, wiedza na tematy teologiczne jest przekazana niezwykle „prostym”, komunikatywnym językiem, zrozumiałym nawet dla laika. Wyjaśnienie haseł ma bardzo przejrzysty układ każda myśl w wyjaśnieniu pojęcia jest wyróżniona akapitem bądź podpunktem, dzięki czemu czytelnik otrzymuje przejrzystą, usystematyzowaną, skondensowaną definicję.

Dzięki zwięzłości prowadzenia myśli, obfitej w treści, Autor uzyskuje, odmienną od innych autorów dzieł tego typu, interpersonalny dialog z czytelnikiem. Otóż większość znanych mi słowników, encyklopedii cechuje się „suchym” podaniem definicji, w którym autorzy popisują się wiedzą poprzez nagromadzenie skrótów myślowych i bardzo trudnego słownictwa, przez co nie starają się zbudować żadnych relacji z odbiorcami, czyniąc z nich jedynie bądź publiczność oklaskującą ich kunszt, bądź przedmioty komunikacji słownej. Słownik podstawowych pojęć teologicznych ks. abp. E. Ozorowskiego jest inny. Autor w nim poprzez użycie komunikatywnego języka, aczkolwiek nie pozbawionego specjalistycznych terminów podawanych w niezwykle przejrzysty sposób, buduje swoistą podmiotową relację z czytelnikiem. Na wzór Dziejów sześciu pojęć: sztuki, piękna, formy, twórczości, odtwórczości, przeżycia estetycznego" W. Tatarkiewicza (Warszawa, 1975 r.), ks. Arcybiskup nie tyle przekazuje wiedzę, ile ją opowiada. Słownik czyta się zatem nie jako typowy zbiór terminów, lecz jak przygodową książkę, w której bohaterami są specjalistyczne pojęcia teologiczne. Dzięki tej mistrzowskiej dynamice słowa Autor czyni z czytelnika interlokutora dialogu naukowego. Jest to swoisty urok tegoż dzieła i stanowi jego piękno. Polega ono zaś na połączeniu ogromnej erudycji Autora z komunikatywnym stylem przekazu wiedzy na określony temat.

\section{Obiektywność}

Obiektywność sądu wypowiadanego przez Autora w danej definicji wynika $\mathrm{z}$ omówionej wcześniej podmiotowej relacji z czytelnikiem. Za przykład w tej materii może posłużyć konkluzja hasła „Pełnia”: „Człowiek został stworzony na obraz i podobieństwo Boże (Rdz 1, 26-27). (...) Skutkiem Wcielenia, ziemskiego życia, śmierci i zmartwychwstania Chrystusa jest Kościół - Jego Ciało. Kościół z tego względu jest pełnią Chrystusa. Bóg powziął postanowienie «dokonania pełni czasów, aby wszystko na nowo zjednoczyć w Chrystusie jako Głowie» (Ef 1, 10). Kościól, będąc pełnią Chrystusa, prowadzi innych do udziału w tej pełni. 
(...) Eschatologiczna pełnia człowieka - to doskonałe jego upodobnienie się do Boga w Komunii osób" (s. 194-195). W przytoczonym fragmencie Słownika widać sugestywną obiektywność wypowiedzi, pozbawioną emocjonalności, kunsztem wyprowadzonym z retoryki Pawłowej. Ksiądz Arcybiskup bowiem w sposób obiektywny podaje definicje. Nie ma w nich ani zmuszania odbiorcy do przyjęcia stanowiska, ani moralizatorstwa, które przecież nie miałoby racji bytu w dziele tego typu. Jednak ze względu na podmiotowość relacji, w Słowniku pobrzmiewa dyskretna nutka teologii moralnej. Nie przekracza ona jednak granicy obiektywności, lecz znajduje się w samym jej centrum. Prawda, którą pragnie przekazać ks. Arcybiskup - niejako w odpowiedzi na liberalistyczne, relatywistyczne prądy postmodernistyczne osaczające współczesnego człowieka - ogniskuje się w antropologii teologicznej - „człowiek - obrazem Boga”; „Jezus - Chrystusem”; „Kościół - drogą do Boga”; „życie Boże - celem ludzkiej egzystencji”. Prawdę tę Autor czerpie z Pisma św. i w delikatny sposób uwrażliwia na nią czytelnika. Tezy, zawarte $\mathrm{w}$ „Słowniku” nie mają nic z subiektywizmu, choć mogą stać się przedmiotem dyskusji w gronie tzw. „chrześcijan anonimowych”. Są obiektywne, ponieważ przywołane wprost z Pisma Świętego, prostują pokręcone drogi ludzkiego myślenia.

Obiektywność prezentowanego Słownika polega zatem na dwóch składowych, komplementarnych elementach. Po pierwsze, ks. Arcybiskup posługuje się tezami opartymi o Pismo Święte, nic nie ujmując ani niczego nie dodając. Po drugie, poprzez prezentację zagadnień jest wierny Magisterium Kościoła, przez co wchodzi w swoisty dialog z odbiorcą, otwierając go na jedyną Prawdę odnoszącą się do ontologicznej i etycznej rzeczywistości każdego człowieka, odkrywając przed nim porządki jego bytu: stworzenia, zbawienia i celu ostatecznego.

\section{Zwięzłość wypowiedzi}

Rzymski retor, Cyceron, w sztuce mówienia zwracał uwagę na najważniejsze zadanie każdego autora wypowiedzi, a mianowicie na pobudzenie serc ludzkich do pozytywnych wzruszeń, wyrażających istotę człowieczeństwa. Ten cel zdaje się również przyświecać ks. Arcybiskupowi. W Słowniku widać dbałość Autora o kulturę słowa. Konstatacje odznaczają się precyzją, przejrzystością, sugestywnością, wręcz melodyjnością słowa pisanego. Styl wypowiedzi znajduje się na pograniczu dwóch stylów: naukowego i popularnonaukowego. Cechuje go ścisłość, precyzja, jednoznaczność sformułowań, jasność sądów, brak elementów emocjonalnych. Jednak tym, co pozwala sytuować Słownik na pograniczu obu tych stylów jest prostota wypowiedzi, ale nie prozaizmy. Kiedy podkreślam prostotę wypowiedzi, mam na myśli unikanie przez Autora zdań o skomplikowanej budowie przy jednoczesnym stosowaniu terminologii naukowej oraz dyskretny sposób obrazowania, w którym są wyjaśnione specjalistyczne pojęcia. Nawet gdy przy omawianym pojęciu jest podawana jego etymologiczna geneza, to Autor 
czyni to z wyczuciem, bez obciążania percepcji intelektualnej czytelnika. Składnia zdań opiera się najczęściej na zdaniach prostych. Zdania wielokrotnie złożone $\mathrm{z}$ trzema lub więcej orzeczeniami występują rzadko, dzięki czemu uzyskana została przejrzystość prowadzenia myśli. Zdania są twierdzące, budowane $\mathrm{w}$ formie czynnej, co daje im większą siłę oddziaływania na czytelnika i umożliwiają mu szybkie zrozumienie wyjaśnianych haseł. Autor swobodnie i precyzyjnie formułuje enuncjacje. Odznaczają się one erudycją przy jednocześnie zachowanej prostocie prezentowania sądów. Wyjaśnienia pojęć cechują się skondensowaną myślą, ale nie skrótem myślowym. Każdy termin jest wyjaśniony w sposób wyczerpujący, bez nagromadzenia ozdobników czy dygresji, które mogłyby spowodować odbiegnięcie od tematu. Zwięzłość wypowiedzi w stylu Słownika zatem polega na rygorystycznym trzymaniu się tematu - oszczędność słów - przy jednoczesnym wyczerpującym wykładzie teologicznym. Dzięki temu Ksiądz Arcybiskup w sugestywnym przybliżaniu czytelnikom pojęć teologicznych, stworzył wyjątkowe dzieło z pogranicza teologii dogmatycznej i moralnej - wyłożona nauka Magisterium Kościoła wzywa odbiorcę do zajęcia określonej postawy światopoglądowej.

Ksiądz arcybiskup Edward Ozorowski w Słowniku podstawowych pojęć teologicznych zawarł, zgodnie z zamierzeniem nakreślonym we Wstępie, „podstawowe pojęcia z obszaru prawdy objawionej" (s. 12). Cel ten został zrealizowany po mistrzowsku. Komunikatywność przekazu, zwięzłość wypowiedzi, przejrzystość naukowego wywodu to techniczne zalety owego dzieła. Dodajmy do tego osobowościowe wartości: obiektywność, dyskretny przekaz uniwersalnej prawdy objawionej, podmiotowość w traktowaniu odbiorcy, a będziemy mieli prawdziwe dzieło, po które powinien sięgnąć każdy człowiek, niezależnie od światopoglądu czy przynależności religijnej.

Anna Dzięgielewska

Uniwersytet w Bialymstoku 